\title{
Protein pattern analysis in tolerant and susceptible wheat cultivars under salinity stress conditions
}

\author{
Marouf KHALILI ${ }^{1}$, Mohammad Reza NAGHAVI ${ }^{2 *}$, Said YOUSEFZADEH ${ }^{2}$
}

Received July 27, 2017; accepted November 19, 2018.

Delo je prispelo 27. julija 2017, sprejeto 19. novembra 2018.

\begin{abstract}
To investigate proteome pattern of wheat cultivars, young leaves were collected from tillering stage of seedlings two weeks after development of the salinity stress. The extraction of proteins from leaf tissue was done and two dimensional electrophoresis using IPG strips and SDS-PAGE in the control and salinity treatments were performed. In total, 198 and 203 protein spots were identified in tolerant ('Moghan3') and susceptible ('Pishtaz') cultivars respectively. Also, among these, spots number 21 and 22 were detected with significant IF in 'Moghan3' and 'Pishtaz' respectively. Two-stage mass spectrometry (MS/MS) was used to identify protein spots. Common identified proteins, including proteins involved in removal of oxidants, Calvin cycle proteins, proteins involved in light reaction of photosynthesis and proton transfer, and heat shock protein were identified on basis of the functional groups and their frequency. In total, 'Moghan3' maintained the stability of the structure and performance of carbon metabolism under stress better than susceptible cultivar. In addition, defense against oxidative stress induced by salinity stress was performed by 2-cys peroxiredoxin BAS1 and $\mathrm{Cu}-$ $\mathrm{Zn}$ SOD proteins that tolerant cultivar defended against oxidative stress better than the susceptible cultivar. The greatest strength of 'Moghan3' and major weakness in 'Pishtaz' are relying on the unique proteins formed under salinity stress for the removal of oxidants and to maintain the activity of the photosynthetic light reactions, respectively.
\end{abstract}

Key words: proteomics analysis; salt tolerance; stress response proteins; two-dimensional electrophoresis; wheat

\section{IZVLEČEK}

\section{ANLIZA VZORCA BELJAKOVIN V ODPORNI IN OBČUTLJIVI SORTI PŠENICE V RAZMERAH SLANOSTNEGA STRESA}

Za analizo proteomskega vzorca $\mathrm{v}$ dveh sortah pšenice so bili vzorčeni mladi listi v fazi bilčenja dva tedna po izpostavitvi slanostnemu stresu. Izvleček beljakovin iz listnih tkiv je bil narejen $\mathrm{z}$ dvodimenzionalno elektroforezo $\mathrm{z}$ uporabo IPG trakov in SDS-PAGE, za rastline iz kontrole in tiste $v$ slanostnem stresu. Celokupno je bilo evidentiranih 198 beljakovinskih točk za odporno sorto ('Moghan3') in 203 beljakovinskih točk za občutljivo sorto ('Pishtaz'). Med temi sta bili ugotovljeni beljakovinski točki št. 21 in $22 \mathrm{z}$ značilnimi vrednostmi IF za 'Moghan3' in 'Pishtaz'. Za določitev beljakovin $\mathrm{v}$ točkah je bila uporabljena dvofazna masna spektrometrija (MS/MS). Določene beljakovine so obsegale encime, ki so vključeni pri odstranjevanju oksidantov, encime Kalvinovega cikla, beljakovine, ki so udeležene $\mathrm{v}$ svetlobnih reakcijah fotosinteze in $\mathrm{v}$ protonskem transportu ter beljakovine vročinskega udara. Beljakovine so bile določene na osnovi funkcionalnih skupin in njihove frekvence. V splošnem je $\mathrm{v}$ stresnih razmerah odporna sorta 'Moghan3' ohranjala stabilnost zgradbe in poteka presnove ogljika bolje kot občutljiva sorta. Dodatno sta se za obrambo proti oksidacijskem stresu $\mathrm{v}$ razmerah slanosti inducirala dva proteina, 2-cis peroksiredoksin BAS1 in $\mathrm{Cu}-\mathrm{Zn}$ SOD protein, ki sta odporno vrsto ščitila bolje kot občutljivo. Odpornost sorte 'Moghan3' in občutljivost sorte 'Pishtaz' na slanostni stres temelji na edinstvenem vorcu beljakovin, ki se tvorijo v razmerah slanosti za odpravljanje oksidantov in vzdrževanje aktivnosti svetlobnih rekacij fotosinteze.

Ključne besede: proteomska analiza; odpornost na sol; stresni proteini; dvodimenzionalna elektroforeza; pšenica

\footnotetext{
1 Associate Professor, Department of Agriculture, Payame Noor University, PO BOX 19395-3697 Tehran, Iran

2 Assistant Professor, Department of Agriculture, Payame Noor University, PO BOX 19395-3697 Tehran, Iran; corresponding author: mr_naghavi@ymail.com
} 


\section{INTRODUCTION}

Salinity stress tolerance in plants is a complex phenomenon and it is communicated with the physiological, biochemical and molecular mechanism. In this regard, proteomic approaches are identified as one of the most important methods for understanding the molecular basis of salt stress tolerance at the protein levels (Thiellement et al., 2002). Abiotic stresses such as salinity, before any effects are detected at the production level cause the change in cytoplasmic calcium concentration and $\mathrm{pH}$ which is understood as the main plant response mechanism under these condition. Osmotic stress and ion toxicity (sodium and chloride) derived from salinity stress act in both the inner and outer plasma membrane by trans-membrane proteins or enzymes inside cytosol. Many osmotics raised under drought stress are understood as stress sensors (Abdul Kader and Lindberg, 2010). Salt interferes with plant growth and can lead to physiological drought and ionic toxicity. Thus, salinity and drought stresses often affects the physiological aspects of plant metabolism, creating tension (hyperionic and hyper osmotic), and eventually plant will die. Salinity and drought stresses overlap on physiological level because salt in soil decreases the amount of available water and leads to reduced water absorption (Tuteja, 2007).

Salinity stress causes ion stress through the changes in potassium and sodium ion ratios. External sodium ions can have a negative effect on the absorption of calcium ions. Salinity resulted increases in the concentration of sodium and chloride ions in cytosol could be detrimental to the cells. Sodium ion can eliminate membrane potential, thus facilitates the absorption of chloride. High concentration of sodium ions (up to 100 $\mathrm{mM}$ ), is toxic for the cell metabolism and can prevent activity of many essential enzymes, cell division and expansion, causing membrane damage and osmotic imbalance and thus stops the growth. High concentration of sodium ions can lead to the production of reactive oxygen species and reduction of photosynthesis. Potassium is one of the most essential elements required for plant growth. The concentration of potassium ions (due to severe salinity stress) causes osmotic imbalance problem in stomata functions and action of enzymes. Salinity damages cells, reduces leaf transpiration, resulting in the prevention of growth and causing cell intoxication. Salts can accumulate in older leaves and causing cell death (Tuteja, 2007).

Several studies involved in identification of proteins' response to salinity stress have used proteomics approaches. Most of the proteins affected under stress were involved in process of photosynthesis, photorespiration, transduction, metabolism, defense against oxidative stress, ion channels control and folding of proteins (Joseph and Jini, 2010). For example, changes in wheat proteome 30 days after exposure to $125 \mathrm{mM} \mathrm{NaCl}$ in the culture chamber were evaluated and a significant negative correlation between tolerance to salt and sodium concentration in wheat stems were observed. Protein expression change was more than $5 \%$, but the difference between the different groups of protein modifications (over expression, knockdown, disappearance and appearance) was variable from 1 to $8 \%$ under salinity stress (Saqib et al., 2006). In order to better understand the development of wheat roots, Song et al. (2007) established a reference map of the major soluble proteins using a combination of 2-DE and MALDI TOF MS and a total of 450 protein spots were detected with silver staining in a $\mathrm{pH}$ ranges of $4-7$, in which 282 protein spots were identified. These identified proteins grouped into diverse functional categories. In comparison with wheat leave proteome, in root, proteins involved in metabolism and transport increased expression, whereas proteins involved in energy, disease and defense, transcription, and signal transduction were of reduced expression. They also showed that hybridization between two parental lines could be different in protein expression in the offspring in comparison with their parents. Proteomic approach was used to identify the salt stressresponsive proteins in an elite Chinese wheat cultivar, 'Zhengmai 9023', which exhibits a high yield, superior gluten quality and better biotic resistance. Three-weekold seedlings were treated with $\mathrm{NaCl}$ of four different concentrations $(1.0 \%, 1.5 \%, 2.0 \%$, and $2.5 \%)$. The total proteins from the leaves of untreated and $\mathrm{NaCl}-$ treated plants were extracted and separated by twodimensional gel electrophoresis (2D-DIGE). A total of 2358 protein spots were detected on the gels, among which 125 spots showed a significant change in protein abundance, and 83 differentially expressed spots were localised on preparative gels. A total, 52 salt-responsive spots were identified, which were classified into six functional categories that included transport-associated proteins, detoxifying enzymes, ATP synthase, carbon metabolism proteins, protein folding proteins, and proteins with unknown biological functions. Of the 52 differentially expressed proteins, 26 were upregulated, 21 were downregulated, and five spots showed multiexpression patterns. In particular, some important proteins for salt tolerance were found to be upregulated in this cultivar under salt stress, such as $\mathrm{H}^{+}$-ATPases, glutathione S-transferase, ferritin and triose phosphate isomerase (Gao et al., 2011). On the other hands, proteomic investigation have been conducted to further understand the mechanism of plant responses to salinity in a salt-tolerant ('Afzal') and a salt-sensitive ('Line 527') genotype of barley. At the 4-leaf stage, plants 
were exposed to 0 (control) or $300 \mathrm{mM} \mathrm{NaCl}$. Salt treatment was maintained for 3 weeks. Total proteins of leaf were extracted and separated by two-dimensional gel electrophoresis. More than 500 protein spots were reproducibly detected. Of these, 44 spots showed significant changes to salt treatment compared to the control: 43 spots were upregulated and 1 spot was downregulated. Using MALDI-TOF-TOF MS, 44 cellular proteins were identified, which represented 18 different proteins and were classified into seven categories and a group with unknown biological function. These proteins were involved in various many cellular functions. Upregulation of proteins which were involved in reactive oxygen species scavenging, signal transduction, protein processing and cell wall may increase plant adaptation to salt stress (Fatehi et al., 2012).

This study compares two-dimensional electrophoresis pattern of salinity susceptible and tolerant wheat cultivars and ultimately, identification of expression changes and evaluation role of identified proteins under salinity stress.

\section{MATERIALS AND METHODS}

\subsection{Plant material and experimental design}

In this study, two cultivars of spring wheat namely 'Moghan3' (tolerant) and 'Pishtaz' (susceptible) at seedling stage in hydroponic culture system under salinity stress were evaluated in the greenhouse at University of Mahabad, Iran in 2015. Hoagland solution specifications used in wheat culture was mixture of $\mathrm{NO}_{3}$ $=15 \mathrm{mM}, \mathrm{K}=6 \mathrm{mM}, \mathrm{Mg}=2 \mathrm{mM}, \mathrm{Zn}=8 \mathrm{mM}, \mathrm{B}=100$ $\mathrm{mM}, \mathrm{Mn}=8 \mathrm{mM}, \mathrm{Cu}=2 \mathrm{mM}, \mathrm{Mo}=2 \mathrm{mM}, \mathrm{Ca}=5 \mathrm{mM}$ and $\mathrm{Fe}$ as $\mathrm{Fe}-\mathrm{EDTA}=4 \mathrm{mg} \mathrm{l}^{-1}$. Experimental plots were tubes which were filled with sandy loam soil and were connected with nutrition source. The plant material was evaluated with factorial experiment based on Randomized Complete Block Design (RCBD) with four replications. The first factor included two levels of salinity exposed with chloride sodium such as control (non-stress) and $250 \mathrm{mM}(\mathrm{NaCl})$ (as severe stress) and the second factor was wheat, above mentioned cultivars. Salinity started from tillering stage for two weeks and then treatments were sampled for proteome analysis. The rest of leaf samples were used for measuring of leaf water potential with pressure chamber, leaf relative water content by Morant-Manceau et al. (2004) method, osmotic potential by osmometer. Also, chlorophyll content (SPAD) and chlorophyll fluorescence was identified by chlorophyll meter and fluorometer respectively. In final, plant height and plant dry mass were measured.

\subsection{Proteome analysis}

\subsubsection{Protein extraction}

Total protein were extracted from $0.5 \mathrm{~g}$ frozen leaf for each biological replicate and it suspended as fine powder in cold acetone containing $10 \%$ TCA and $0.07 \%$ 2-mercapthoetanol. The resultant powder was dissolved in lysis buffer containing $7 \mathrm{M}$ urea, $2 \mathrm{M}$ thiourea, $2 \%$ CHAPS, $60 \mathrm{mM}$ DDT and $1 \%$ ampholyte $(\mathrm{pH}: 3$ - 10). In addition, protein concentration was determined by Bradford assay (Bradford, 1976).

\subsubsection{The first and second dimension electrophoresis}

The first dimension electrophoresis was performed using IPG strips. For the first dimension of PROTEAN IEF focusing tray (Bio Rad) and the PROTEAN IEF cell (Bio Rad) was used. Then balancing of strips (equilibration) was carried out ((Herbert, 1999). Also, the second dimension gels as two pieces (including separator gel (separating gel) and holder gel (stacking gel)) were prepared. The separation gel, $8.5 \mathrm{ml}$, was prepared from the combination of acrylamide, $6.3 \mathrm{ml}$ separating gel buffer $(\mathrm{pH}=8.8), 2 \mathrm{ml}$ distilled water, $120 \mu 110 \%$ APS and $20 \mu \mathrm{l}$ TEMED. While stacking gel was prepared from combining of acrylamide for 1 $\mathrm{ml}$ stacking gel, $1.3 \mathrm{ml}$ stacking gel buffer $(\mathrm{pH}=6.8), 2$ $\mathrm{ml}$ distilled water, $30 \mu \mathrm{l} 10 \%$ APS, and $20 \mu \mathrm{l} \mathrm{TEMED).}$ Then first dimension strips were put on the second dimension gel using agarose $1 \%$. Finally protein loading in second dimension with a current of $35 \mathrm{~mA}$ for each gel was conducted. After the second dimension electrophoresis, gel staining was performed using a solution of Coomassie blue (Herbert, 1999).

\subsubsection{Gel imaging and protein spots analysis}

Gels were scanned using BioRad GS-800 scanner. Images analyses were performed with PDQuest $^{\mathrm{TM}}$ software (BioRad). After determining the protein spots with significant expression and data normalization, a one-way ANOVA model was used to identify the differentially expressed protein spots between normal and stress conditions. Also it was used IF (Induction Factor) measurement for selection among significantly different spots for detecting spots with more expression change during salinity stress. Then the two-stage mass spectrometry (MS/MS) and liquid chromatography combined with bioinformatics tools were used to identify target spots. One microliter of digested peptides was injected into the C18 column of PepMap nanochromatography. The peptides were then diluted with $0.1 \%$ formic acid in acetonitrile and separated in C18 columns by inverting phase movement. Subsequently, 
peptides were sprayed into mass spectrometers. The range of ratio of mass to load in peptides was considered to be between 100 and 2000. The data obtained from the spectrophotometer with Bioworks software (ver. 3.3.1, Thermo Fisher) were converted into a usable format by Mascot search engine.

\section{RESULTS AND DISCUSSION}

\subsection{Analysis of variance and Mean comparisons}

Variance analysis is shown in Table 1. According to the results, between stress levels and cultivars were significant differences for all studied traits. The cultivar $\times$ stress interaction was not significant for any studied traits. The minimum and maximum coefficients of variation were related to SPAD (6.67) and chlorophyll fluorescence (10.18), respectively. Table 2 shows the comparison of the mean of stress levels and cultivars. According to results, quantitative mean of 'Moghan3' cultivar was better than 'Pishtaz' cultivar for all studied traits under salinity stress.

Table 1: Analysis of variance for morphological and physiological traits in wheat under salt stress

\begin{tabular}{|c|c|c|c|c|c|c|c|c|}
\hline \multirow[t]{2}{*}{ S.O.V } & \multirow{2}{*}{$\begin{array}{l}\text { degree of } \\
\text { freedom }\end{array}$} & \multicolumn{7}{|c|}{ Mean of squares } \\
\hline & & $\begin{array}{c}\text { Plant Dry } \\
\text { Mass }\end{array}$ & $\begin{array}{l}\text { Plant } \\
\text { Height }\end{array}$ & Fluorescence & SPAD & $\begin{array}{l}\text { Osmotic } \\
\text { Potential }\end{array}$ & RWC & LWP \\
\hline Replication & 3 & $0.01^{\mathrm{ns}}$ & $36.65^{\mathrm{ns}}$ & $0.003^{\text {ns }}$ & $1.33^{\mathrm{ns}}$ & $0.008^{\mathrm{ns}}$ & $3.67^{\mathrm{ns}}$ & $0.005^{\mathrm{ns}}$ \\
\hline Stress (S) & 1 & $0.98^{* *}$ & $95.56^{* *}$ & $0.010^{* *}$ & $19.25^{* *}$ & $0.34^{* *}$ & $153.01^{* *}$ & $0.38^{*}$ \\
\hline Cultivar (C) & 1 & $0.96^{* *}$ & $98.88^{* *}$ & $0.011^{* *}$ & $20.28^{* *}$ & $0.43^{* *}$ & $169.44^{* *}$ & $0.42^{* *}$ \\
\hline $\mathrm{C} \times \mathrm{S}$ & 1 & $0.04^{\mathrm{ns}}$ & $33.70^{\mathrm{ns}}$ & $0.001^{\mathrm{ns}}$ & $3.88^{\mathrm{ns}}$ & $0.005^{\mathrm{ns}}$ & $2.65^{\mathrm{ns}}$ & $0.003^{\mathrm{ns}}$ \\
\hline Error & 9 & 0.05 & 45.40 & 0.005 & 5.87 & 0.009 & 3.97 & 0.22 \\
\hline $\mathrm{CV}(\%)$ & & 7.34 & 9.66 & 10.18 & 6.67 & 10.08 & 8.50 & 7.53 \\
\hline
\end{tabular}

$\mathrm{ns}, *$ and $* *$ are non-significant and significantly in $5 \%$ and $1 \%$ probability levels respectively.

Table 2: Comparison of of the means for the stress levels and cultivars for studied traits in wheat

\begin{tabular}{|c|c|c|c|c|c|c|c|}
\hline & $\begin{array}{l}\text { Plant Dry } \\
\text { Mass (g) }\end{array}$ & $\begin{array}{l}\text { Plant } \\
\text { Height } \\
(\mathrm{cm})\end{array}$ & Fluorescence & SPAD & $\begin{array}{c}\text { Osmotic } \\
\text { Potential } \\
(\mathrm{MPa})\end{array}$ & $\begin{array}{c}\text { RWC } \\
(\%)\end{array}$ & $\begin{array}{l}\text { LWP } \\
(\mathrm{MPa})\end{array}$ \\
\hline Control & $1.73 \pm 0.02$ & $29.3 \pm 0.7$ & $0.8325 \pm 0.0023$ & $42.1 \pm 0.3$ & $-0.65 \pm 0.02$ & $75.33 \pm 1.40$ & $-1.36 \pm 0.03$ \\
\hline Salt stress & $1.08 \pm 0.04$ & $21.1 \pm 0.9$ & $0.7812 \pm 0.0034$ & $39.8 \pm 0.5$ & $-1.02 \pm 0.02$ & $64.25 \pm 1.23$ & $-1.89 \pm 0.01$ \\
\hline Difference & $\pm 0.65^{* *}$ & $\pm 8.2^{* * *}$ & $\pm 0.0513^{* *}$ & $\pm 2.3^{* *}$ & $\pm 0.37^{* * *}$ & $\pm 11.08^{* *}$ & $\pm 0.53^{*}$ \\
\hline Moghan3 & $1.92 \pm 0.02$ & $31.4 \pm 1.0$ & $0.8992 \pm 0.0020$ & $45.3 \pm 0.4$ & $-1.14 \pm 0.03$ & $79.69 \pm 1.95$ & $-1.06 \pm 0.02$ \\
\hline Pishtaz & $0.88 \pm 0.01$ & $19.5 \pm 0.8$ & $0.7761 \pm 0.0009$ & $38.9 \pm 0.9$ & $-0.53 \pm 0.01$ & $61.04 \pm 0.89$ & $-1.92 \pm 0.03$ \\
\hline Difference & $\pm 1.04^{* *}$ & $\pm 11.9^{* *}$ & $\pm 0.1231^{* *}$ & $\pm 6.4^{* *}$ & $\pm 0.61^{* *}$ & $\pm 18.65^{* *}$ & $\pm 0.86^{* *}$ \\
\hline
\end{tabular}




\subsection{Proteomics results}

\subsubsection{Dimensional Gel Electrophoresis}

Protein analysis discovered 198 and 203 protein spots in tolerant ('Moghan3) and susceptible ('Pishtaz') cultivars, respectively. Following, among significant spots, protein spots with significantly larger IF than 2 or smaller IF than 0.5 were picked (IF more than 1 points the increased protein expression under salt stress). According to IF value, out of 198 and 203 protein spots,
21 and 22 protein spots in 'Moghan' and 'Pishtaz' cultivars were detected, respectively. Out of these protein spots, 16 protein spots between the two cultivars were in common while five and six protein spots were unique for the 'Maghan3' and 'Pishtaz' cultivars, respectively. In other words, a total of 27 responsive protein spots under stress in both cultivars were identified. Gel image for both cultivars, 'Moghan3' and 'Pishtaz' are shown in Figures 1 and 2.
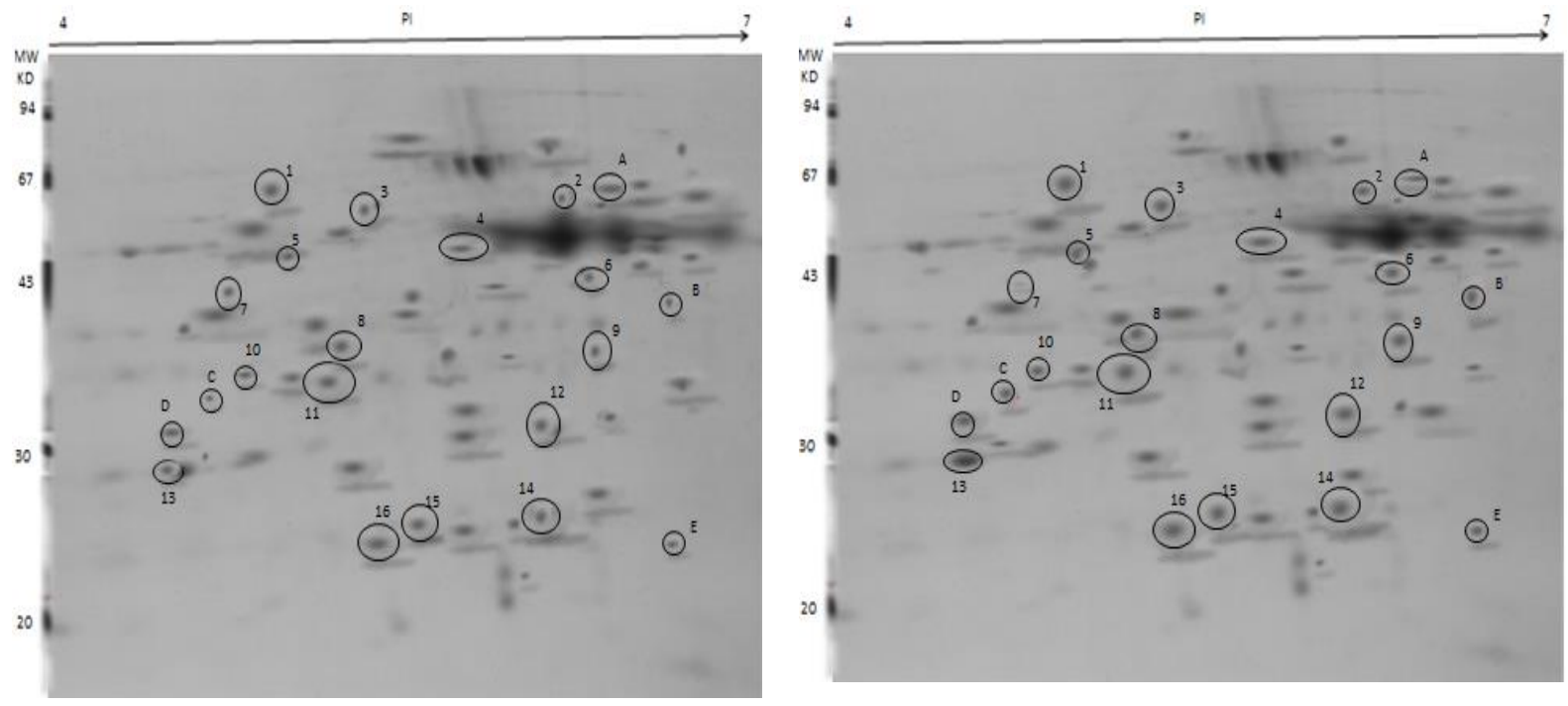

Figure 1: Comparison of 2D gel electrophoresis of 'Moghan3' under control (left) and salinity stress (right). Responsive common protein spots for salt stress are shown with numbers and uncommon protein with letters
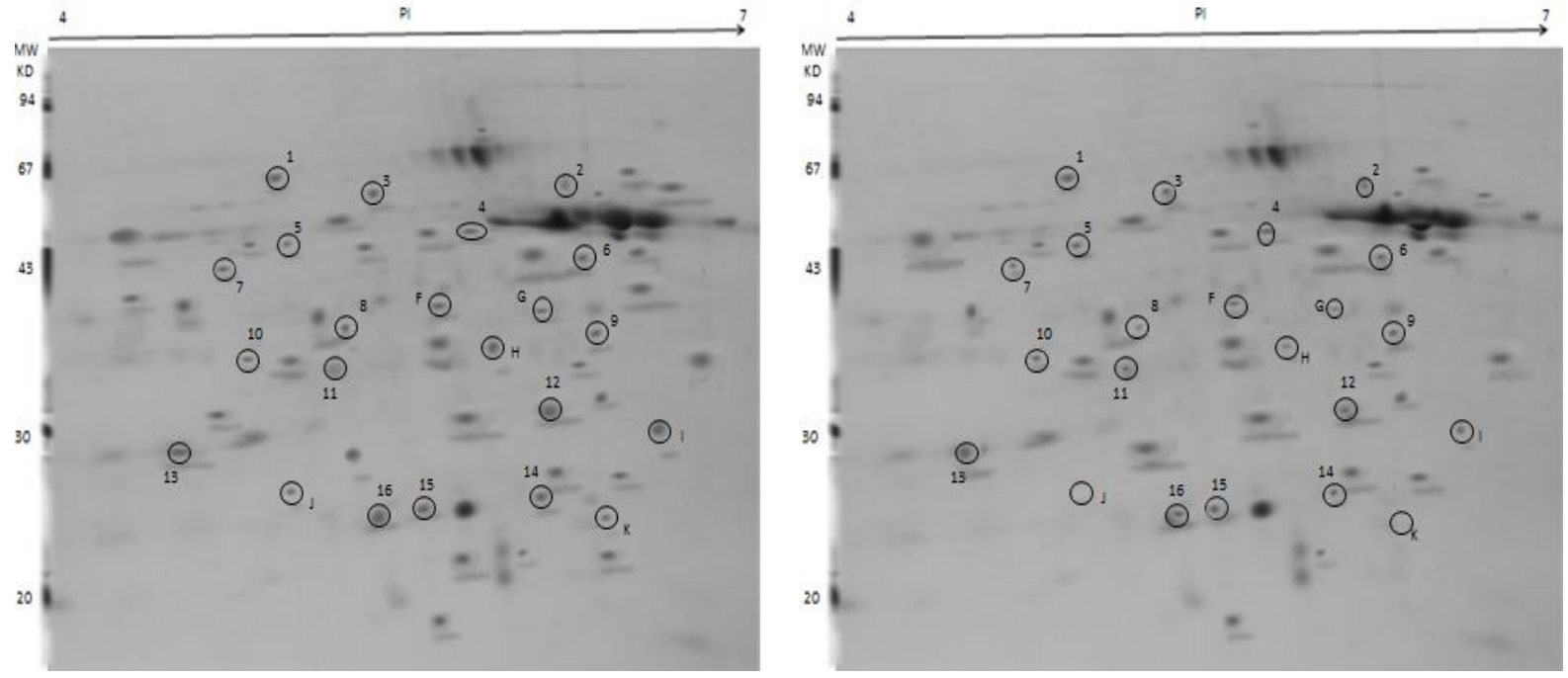

Figure 2: Comparison of 2D gel electrophoresis of 'Pishtaz' under control (left) and salinity stress (right). Responsive common protein spots for salt stress are shown with numbers and uncommon protein with letters 
Based on the results it can be stated that increased expression of proteins in tolerant wheat cultivar under salinity stress was bigger than in susceptible cultivar (Tables 3 and 4). Also tolerant cultivar reaction to maintain its growth was better than in susceptible cultivar under salinity stress. These results are similar to results reported by Hosseini Salekdeh et al. (2002) and Naghavi (2014).

\subsubsection{Protein identification by mass spectrometry}

The responsive proteins to salinity stress on the staining gel were isolated and were identified using mass spectrometry. 16 common proteins and 11 uncommon proteins such as 5 spots in 'Moghan3' and 6 spots in 'Pishtaz' were detected (Tables 3 and 4). Also in Figure 3 numbers of downregulated, upregulated and absent/present proteins in two cultivars are shown The majority of responsive proteins in 'Moghan3' were upregulated while the majority of them in 'Pishtaz' were downregulated by salinity. 
Table 3: Characteristics of 16 known common protein spots from all of significantly different accessions of both wheat cultivar under salinity stress

\begin{tabular}{|c|c|c|c|c|c|c|c|c|c|}
\hline \multirow{2}{*}{$\begin{array}{l}\text { Functional } \\
\text { group of } \\
\text { protein }\end{array}$} & \multirow{2}{*}{$\begin{array}{c}\text { Spot } \\
\text { num } \\
\text { ber }\end{array}$} & \multicolumn{2}{|c|}{$\begin{array}{c}\text { Experimenta } \\
1 \\
\end{array}$} & \multicolumn{2}{|c|}{ Theoretical } & \multirow[b]{2}{*}{ name of protein } & \multirow{2}{*}{$\begin{array}{l}\text { Accession } \\
\text { number }\end{array}$} & \multirow{2}{*}{$\begin{array}{l}\text { Expression } \\
\text { in } \\
\text { 'Moghan3' }\end{array}$} & \multirow{2}{*}{$\begin{array}{l}\text { Expression in } \\
\text { 'Pishtaz' }\end{array}$} \\
\hline & & MW & $\mathrm{pI}$ & MW & $\mathrm{pI}$ & & & & \\
\hline $\begin{array}{c}\text { proton } \\
\text { transport }\end{array}$ & 1 & 65.1 & 4.9 & 53.88 & 5.06 & $\begin{array}{l}\text { ATP synthase CF1 } \\
\text { beta subunit }\end{array}$ & gi|14017579 & upregulated & downregulate \\
\hline $\begin{array}{c}\text { proton } \\
\text { transport }\end{array}$ & 2 & 64.2 & 6.1 & 53.88 & 5.06 & $\begin{array}{c}\text { ATP synthase CF1 } \\
\text { beta subunit }\end{array}$ & gi|14017579 & upregulated & $\begin{array}{l}\text { downregulate } \\
\text { d }\end{array}$ \\
\hline $\begin{array}{l}\text { heat shock } \\
\text { protein }\end{array}$ & 3 & 63.4 & 5.4 & 73.72 & 4.9 & $\begin{array}{c}70 \mathrm{kDa} \text { heat shock } \\
\text { protein }\end{array}$ & gi|254211611 & upregulated & $\begin{array}{c}\text { downregulate } \\
\mathrm{d}\end{array}$ \\
\hline $\begin{array}{l}\text { Calvin } \\
\text { cycle }\end{array}$ & 4 & 50.3 & $\begin{array}{l}5.7 \\
5\end{array}$ & 53.4 & 6.2 & $\begin{array}{c}\text { Ribulose-1,5- } \\
\text { bisphosphate } \\
\text { carboxylase/oxygenas } \\
\text { e, large subunit } \\
\end{array}$ & gi|61378609 & upregulated & downregulate \\
\hline $\begin{array}{l}\text { Calvin } \\
\text { cycle }\end{array}$ & 5 & 45.1 & 5.1 & 47.34 & 8.62 & $\begin{array}{c}\text { ribulose } 1,5- \\
\text { bisphosphate } \\
\text { carboxylase activase } \\
\text { isoform } \\
\end{array}$ & gi|167096 & $\begin{array}{l}\text { further } \\
\text { increase }\end{array}$ & increased less \\
\hline $\begin{array}{c}\text { protein } \\
\text { synthesis/de } \\
\text { gradation } \\
\end{array}$ & 6 & 44.4 & 6.1 & 39.9 & 6.5 & Triticain gamma & gi|111073719 & upregulated & $\begin{array}{c}\text { downregulate } \\
\mathrm{d}\end{array}$ \\
\hline $\begin{array}{l}\text { photoreactio } \\
\text { n of } \\
\text { photosynthe } \\
\text { sis } \\
\end{array}$ & 7 & 42.9 & 4.7 & 37.01 & 5.4 & $\begin{array}{l}\text { photosystem II } \\
\text { stability/assembly } \\
\text { factor HCF136, } \\
\text { chloroplastic-like }\end{array}$ & gi|357117071 & decrease less & $\begin{array}{l}\text { further } \\
\text { decrease }\end{array}$ \\
\hline $\begin{array}{c}\text { removal of } \\
\text { oxidants }\end{array}$ & 8 & 38.3 & 5.3 & 27.9 & 5.6 & acidic endochitinase & gi|116346 & upregulated & $\begin{array}{c}\text { downregulate } \\
\mathrm{d}\end{array}$ \\
\hline $\begin{array}{l}\text { Calvin } \\
\text { cycle }\end{array}$ & 9 & 38.1 & $\begin{array}{l}6.1 \\
5\end{array}$ & 18.80 & 8.83 & $\begin{array}{c}\text { ribulose-1,5- } \\
\text { bisphosphate } \\
\text { carboxylase/oxygenas } \\
\text { e small subunit }\end{array}$ & gi|4038719 & upregulated & $\begin{array}{c}\text { downregulate } \\
\mathrm{d}\end{array}$ \\
\hline $\begin{array}{l}\text { removal of } \\
\text { oxidants }\end{array}$ & 10 & 37.3 & 4.8 & 29.5 & 10.2 & HrPB1 & gi|38679331 & $\begin{array}{c}\text { further } \\
\text { increase }\end{array}$ & increased less \\
\hline $\begin{array}{l}\text { removal of } \\
\text { oxidants }\end{array}$ & 11 & 36.5 & 5.2 & 20.35 & 5.3 & $\begin{array}{l}\mathrm{Cu} / \mathrm{Zn} \text { superoxide } \\
\text { dismutase }\end{array}$ & gi|1572627 & upregulated & $\begin{array}{l}\text { downregulate } \\
\text { d }\end{array}$ \\
\hline $\begin{array}{c}\text { Calvin } \\
\text { cycle }\end{array}$ & 12 & 33.1 & $\begin{array}{c}5.9 \\
5\end{array}$ & 42.21 & 5.9 & $\begin{array}{l}\text { chloroplast fructose- } \\
\text { bisphosphate aldolase }\end{array}$ & gi|223018643 & upregulated & $\begin{array}{c}\text { downregulate } \\
\mathrm{d}\end{array}$ \\
\hline $\begin{array}{l}\text { removal of } \\
\text { ioxidants }\end{array}$ & 13 & 28.9 & 4.6 & 23.39 & 5.4 & $\begin{array}{l}\text { 2-cys peroxiredoxin } \\
\text { BAS1, chloroplastic }\end{array}$ & gi|2499477 & $\begin{array}{c}\text { further } \\
\text { increase }\end{array}$ & increased less \\
\hline $\begin{array}{c}\text { removal of } \\
\text { oxidants }\end{array}$ & 14 & 26.0 & 5.9 & 23.39 & 5.4 & $\begin{array}{l}\text { 2-cys peroxiredoxin } \\
\text { BAS1, chloroplastic }\end{array}$ & gi|2499477 & upregulated & $\begin{array}{c}\text { downregulate } \\
\mathrm{d}\end{array}$ \\
\hline $\begin{array}{l}\text { photoreactio } \\
\text { n of } \\
\text { photosynthe } \\
\text { sis } \\
\end{array}$ & 15 & 25.2 & 5.6 & 27.42 & 8.84 & $\begin{array}{l}\text { oxygen-evolving } \\
\text { enhancer protein } 2 \text {, } \\
\text { (OEE2) chloroplastic }\end{array}$ & gi|131394 & upregulated & $\begin{array}{c}\text { downregulate } \\
\text { d }\end{array}$ \\
\hline $\begin{array}{l}\text { Remove of } \\
\text { antioxidant }\end{array}$ & 16 & 24.1 & 5.5 & 23.39 & 5.4 & $\begin{array}{l}\text { 2-cys peroxiredoxin } \\
\text { BAS1, chloroplastic }\end{array}$ & gi|2499477 & upregulated & $\begin{array}{c}\text { downregulate } \\
\text { d }\end{array}$ \\
\hline
\end{tabular}


Marouf KHALILI et al.

Table 4: Characteristics of five uncommon protein spots in 'Moghan3' and six uncommon spots in 'Pishtaz' under salinity stress

\begin{tabular}{|c|c|c|c|c|c|c|c|c|c|}
\hline \multirow{2}{*}{$\begin{array}{l}\text { Functional } \\
\text { group of } \\
\text { protein }\end{array}$} & \multirow{2}{*}{$\begin{array}{l}\text { Spot } \\
\text { code }\end{array}$} & \multicolumn{2}{|c|}{ Experimental } & \multicolumn{2}{|c|}{ Theoretical } & \multirow{2}{*}{$\begin{array}{c}\text { name of } \\
\text { protein }\end{array}$} & \multirow{2}{*}{$\begin{array}{c}\text { Accession } \\
\text { number }\end{array}$} & \multirow{2}{*}{$\begin{array}{l}\text { Expression } \\
\text { in`Moghan3 }\end{array}$} & \multirow{2}{*}{$\begin{array}{l}\text { Expression } \\
\text { in 'Pishtaz' }\end{array}$} \\
\hline & & MW & $\mathrm{pI}$ & MW & $\mathrm{pI}$ & & & & \\
\hline $\begin{array}{c}\text { heat shock } \\
\text { protein }\end{array}$ & A & 65.2 & 6.18 & 73.72 & 4.9 & $\begin{array}{c}70 \mathrm{kDa} \text { heat } \\
\text { shock protein }\end{array}$ & gi|254211611 & $\begin{array}{c}\text { downregulat } \\
\text { ed }\end{array}$ & - \\
\hline $\begin{array}{c}\text { protein } \\
\text { synthesis/de } \\
\text { gradation }\end{array}$ & $\mathrm{B}$ & 39.9 & 6.3 & 24.4 & 10.1 & $\begin{array}{l}\text { 50S ribosomal } \\
\text { protein } \mathrm{L} 10\end{array}$ & gi|218192573 & upregulated & - \\
\hline $\begin{array}{c}\text { removal of } \\
\text { oxidants }\end{array}$ & $\mathrm{C}$ & 34.1 & 4.68 & 29.52 & 9.51 & HrPB1 & gi|38679331 & upregulated & - \\
\hline $\begin{array}{c}\text { removal of } \\
\text { oxidants }\end{array}$ & $\mathrm{D}$ & 32.0 & 4.61 & 17 & 5.37 & $\begin{array}{c}\text { Type } 2 \\
\text { peroxiredoxin }\end{array}$ & gi|473787383 & upregulated & - \\
\hline $\begin{array}{l}\text { removal of } \\
\text { oxidants }\end{array}$ & $\mathrm{E}$ & 24.3 & 6.35 & 20.35 & 5.3 & $\begin{array}{c}\mathrm{Cu} / \mathrm{Zn} \\
\text { superoxide } \\
\text { dismutase }\end{array}$ & gi|1572627 & upregulated & - \\
\hline $\begin{array}{l}\text { photoreactio } \\
\text { n of } \\
\text { photosynthe } \\
\text { sis }\end{array}$ & $\mathrm{F}$ & 39.9 & 5.7 & 24.44 & 8.69 & $\begin{array}{c}\text { light- } \\
\text { harvesting } \\
\text { complex I, } \\
\text { partial } \\
\text { (chloroplast) }\end{array}$ & gi|544700 & - & $\begin{array}{c}\text { downregula } \\
\text { ted }\end{array}$ \\
\hline $\begin{array}{l}\text { photoreactio } \\
\text { n of } \\
\text { photosynthe } \\
\text { sis }\end{array}$ & $\mathrm{G}$ & 39.5 & 5.9 & 28.6 & 7.7 & $\begin{array}{c}\text { thylakoid } \\
\text { lumenal } 29.8 \\
\text { kDa protein }\end{array}$ & gi|195656049 & - & $\begin{array}{c}\text { downregula } \\
\text { ted }\end{array}$ \\
\hline $\begin{array}{c}\text { removal of } \\
\text { oxidants }\end{array}$ & $\mathrm{H}$ & 37.2 & 5.85 & 23.6 & 5.8 & $\begin{array}{c}\text { glutathione S- } \\
\text { transferase }\end{array}$ & gi|5923877 & - & $\begin{array}{c}\text { downregula } \\
\text { ted }\end{array}$ \\
\hline $\begin{array}{l}\text { removal of } \\
\text { oxidants }\end{array}$ & I & 31.1 & 6.28 & 27.96 & 5.0 & $\begin{array}{c}\text { ascorbate } \\
\text { peroxidase }\end{array}$ & gi|15808779 & - & $\begin{array}{c}\text { downregula } \\
\text { ted }\end{array}$ \\
\hline $\begin{array}{l}\text { proton } \\
\text { transport }\end{array}$ & $\mathrm{J}$ & 27.0 & 5.1 & 17.72 & 4.49 & $\begin{array}{l}\text { ATP synthase } \\
\text { delta chain, } \\
\text { chloroplastic }\end{array}$ & gi|475627717 & - & $\begin{array}{c}\text { absent } \\
\text { under stress }\end{array}$ \\
\hline $\begin{array}{l}\text { photoreactio } \\
\text { n of } \\
\text { photosynthe } \\
\text { sis }\end{array}$ & $\mathrm{K}$ & 23.5 & 6.2 & 27.42 & 8.84 & $\begin{array}{c}\text { oxygen- } \\
\text { evolving } \\
\text { enhancer } \\
\text { protein } 2 \text {, } \\
\text { chloroplastic }\end{array}$ & gi|131394 & - & $\begin{array}{c}\text { absent } \\
\text { under stress }\end{array}$ \\
\hline
\end{tabular}




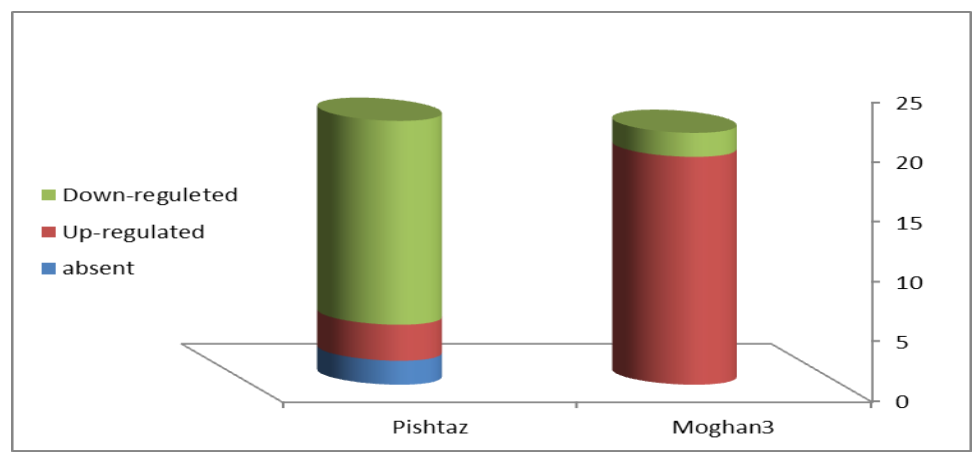

Figure 3: Number of protein spots in two cultivars of wheat under salinity stress

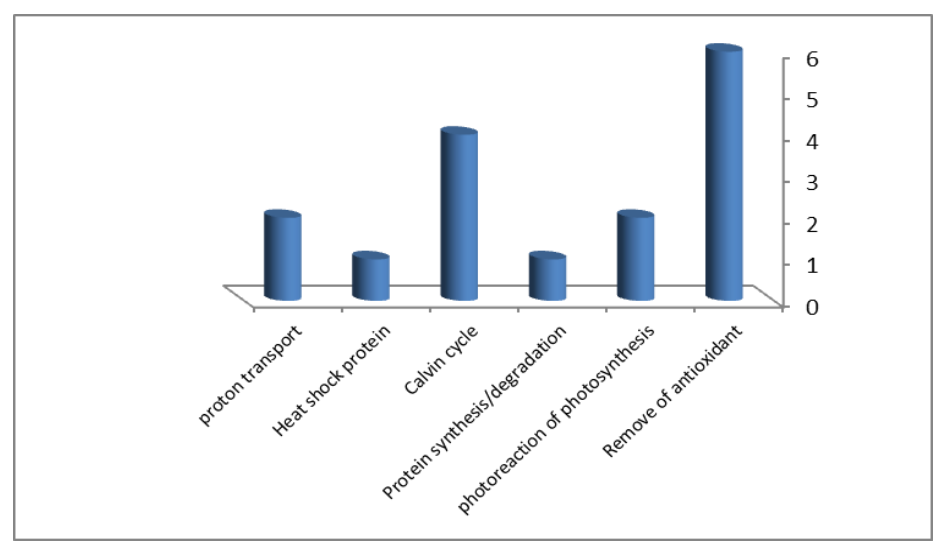

Figure 4: Number of common specific proteins in two cultivars of wheat under salinity stress

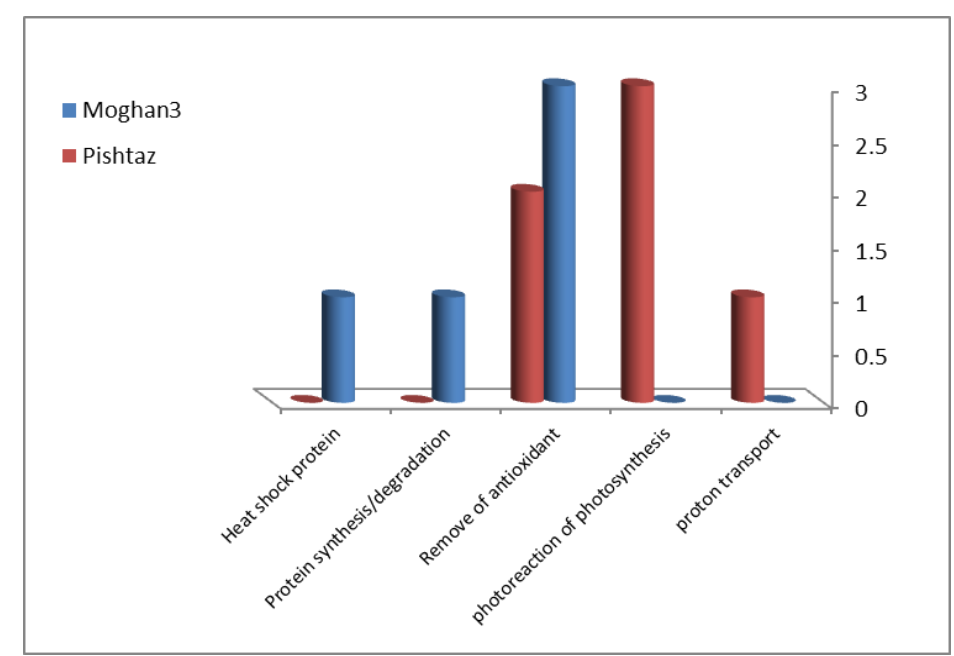

Figure 5: Number of uncommon specific proteins in two cultivars of wheat under salinity stress

3.2.3 Classification responsive proteins in two cultivars of wheat

A total 16 common protein spots were identified between tolerant and susceptible cultivars under salinity stress with difference expression (Table 3). According to Figure 4 the majority of these proteins are inside the cell, involved in removal of antioxidants (6 proteins), the Calvin cycle (4 proteins), light reaction of photosynthesis (2 proteins), proton transport (2 proteins), heat shock proteins (1 proteins) and protein involved in protein synthesis/degradation (1 protein), respectively. These results are similar to results reported 
by Mittler (2002) and Noreen and Ashraf (2008). A correlation between the antioxidant enzyme activities and salinity tolerance was demonstrated by comparison of tolerant cultivar with sensitive cultivar. These activities were ascribed to increased protein expression under salinity stress and are closely related to salt tolerance in many plants (Athar et al., 2008). In addition, five protein spots were unique to the tolerant cultivar ('Moghan3') and had more to do with the removal of antioxidants. Due to expression increase of these proteins, this cultivar has stronger cellular detoxification system (Table 4, Figure 5). Six protein spots were seen uniquely in the sensitive cultivar ('Pishtaz') wherer the majority of proteins were related to photosynthetic light reaction (Table 4, Figure 5). According to results their decreased expression could be a cause for the reduction in the performance of photosynthesis under salinity stress in susceptible cultivar.

On the whole, the protein expression pattern in control (non-stress) and stress conditions were inserted into 4 groups (state) such as: a - proteins with reduced expression in both susceptible and tolerant cultivars (like protein 7) .b - proteins with increased expression in tolerant and reduce expression in susceptible cultivar (like protein 1), c - proteins present uniquely in the tolerant cultivar (such as A code protein), $\mathrm{d}$ - proteins only in the susceptible cultivar (such as $\mathrm{H}$ code protein) (Twyman, 2004).

\section{Defense against oxidative stress}

From total of common proteins 6 of them were related to removal of oxidants. The presence of 2-cys peroxiredoxin BAS1, chloroplastic (spots no. 13, 14 and 16), acidic endochitinase (spots no. 8), Harpin binding protein 1 (HrPB1) (spots No. 10) and Cu/Zn superoxide dismutase (spots No. 11), were induced under salinity stress in both cultivars (Table 3, Figure 1, 2, 4). On the other hands, 3 unique proteins (uncommon proteins) such as HrPB1 ( $\mathrm{C}$ code), type 2 peroxiredoxin ( $\mathrm{D}$ code) and $\mathrm{Cu} / \mathrm{Zn}$ superoxide dismutase (E code) were identified related to remove antioxidant were upregulated in 'Moghan3' under salinity stress (Figure 3 , Table 4). While, 2 unique proteins such as glutathione $\mathrm{S}$-transferase ( $\mathrm{H}$ code) and ascorbate peroxidase (I code) were identified related to remove of oxidants were downregulated in 'Pishtaz' (Figure 3, Table 4). Superoxide dismutase (SOD) proteins are in fact, the first defense line against ROS, which convert superoxide into hydrogen peroxide which is less toxic. In the absence of sufficient carbon dioxide as the final receptor of electrons, electrons migrate from the photosynthetic membrane to oxygen molecules via the Mehler reaction and generate superoxide ions (Cakmak, 2005). In response to salinity stress, one protein spot named chloroplast $\mathrm{Cu}-\mathrm{Zn}$ SOD (No. 11 spot) in susceptible cultivar ('Pishtaz') showed decreased expression, but besides that in 'Moghan 3', protein spot with $\mathrm{E}$ code increases expression, as showed in Tables 3 , 4. In line with these results, SOD accumulation in rice tolerant cultivar and its reduction in susceptible cultivars have been reported in response to salinity stress (Komatsu and Tanaka, 2004). Lower amount of this protein in stressed leaves of 'Pishtaz' caused a high level of hydroxyl radicals in the chloroplasts of this cultivar. In other words, under salinity stress conditions when increased production of ROS takes place, the disturbed balance between their production and elimination, especially in the tolerant genotypes is ameliorated by altering the expression of proteins associated with cellular homeostasis, the cell's balance is reestablished (Sun et al., 2006). On the other hand, peroxiredoxin proteins are expressed extensively in the tissues and are found in mitochondria and cytosols. The cell's location of these proteins, expresses the crucial role of antioxidants in the cellular organells that are the main source of ROS. These proteins, in addition to antioxidant activity, are also active in controlling signal transduction. The N-terminal of this protein, which contains cysteine, is oxidized to sulfenic acid, which acts as a bridge to react with peroxides. In fact, copper/zinc superoxide dismutase enzyme activity has been transformed ROS to $\mathrm{H}_{2} \mathrm{O}_{2}$, and the type 2 peroxiredoxin enzyme recovers $\mathrm{H}_{2} \mathrm{O}_{2}$ molecule, and in many studies, peroxirdoxin protein has been suggested as a protein responding to stress (Hashimoto et al ., 2009). The presence and activation of this protein in the 'Moghan 3' (spot No. 13, 14 and 16) shows the role of this protein in tolerance to salinity stress (Figure 1, 2 and Table 3). In general, due to the change of these proteins under salinity stress, reaction of 'Moghan3' was better than 'Pishtaz' as removal of antioxidant proteins.

\section{Photosynthesis and carbon metabolism}

Splitting of water by light takes place in the OEC (Oxygen-evolving complex) reaction center of photosystem II (Heide et al., 2004). The subunit of the PSII complex is the protein involved in the photosynthetic water splitting system known as OEC proteins and contributes to the stability of the PSII complex (Ifuku et al., 2008) and disruption of these proteins causes light damage to photosystem II (Takahashi and Murata, 2008). Therefore, due to reduced expression or lack of expression of this protein in the 'Pishtaz' (susceptible cultivar) (spot No. 15 and spot code K, Table 3, 4), the activity of photosystem II and eventually the efficiency of photosynthetic light reaction be reduced in this cultivar while this protein (Spot No. 15) showed increased expression (upregulated) in tolerant cultivar ('Moghan3'). These 
results indicate that under salinity stress, one of the important components of the photosynthesis machine, namely the oxygen swirling and the photosystem II complex has strongly affected, thus contributing to the aging of the leaves and possibly the gradual death of the cells. Komatsu and Tanaka (2004) made proteome analysis of leaf sheath in rice under salinity stress caused by sodium chloride. The frequency of this group of proteins in response to salinity stress was increased. It indicated the protective role of this protein against of salinity stress. On the other hands, HCF136 protein is a basic protein for repair, construction and stability of photosystem II complex (Plucken et al., 2002). In this experiment was found decreased expression of this protein in the 'Moghan3' (spot No.7) and further decreased expression in the sensitive 'Pishtaz'(Table 3). These results are similar to proteome analysis reported by Ford et al. (2011). In order to avoid light damage to photosynthetic apparatus, several mechanisms including adjusting absorbing antenna to light (LHC proteins) (spot code F in the 'Pishtaz') and reducing the size of antenna to reduce the absorption of light could be carried out (Eberhard et al., 2008). Our results showed that 'Pishtaz' for preventing of further damage to photosystem machine changed the expression in $\mathrm{F}$ code protein and these results are similar to results reported by Liu et al. (2014). Also, TL29 (thylakoid lumenal $29.8 \mathrm{kDa}$ protein) (spot code G in the 'Pishtaz' with downregulated under stress) is a $29 \mathrm{kDa}$ protein and is located in the thylakoid lumen (Kieselbach et al., 2000). Based on high homology with ascorbate peroxidase (APX) it was previously called also APX4 and was thought to plays a role in protecting cells against reactive oxygen species (Panchuk et al., 2005). Recently, based on testing Granlund et al. (2009) reported that this protein is associated with photosystem II and involved in prevention of photo damage to the photosystem II. So, according to reduced expression of this protein in susceptible cultivar, it could be the reason for decrease of photosystem II performance under salinity stress. In this regards, Zadraznik et al., (2013) reported that accumulation of these proteins and their isomerases in the tolerant genotypes is higher than in susceptible.

$\mathrm{RuBisCO}$ is a key enzyme for fixation of carbon dioxide in photosynthesis. It is formed from several catalyzing large subunits (catalytic large subunits) (spot No. 4) and several regulatory smaller subunits (regulative small subunits) (spot No. 9) (Spreitzer and Salvucci, 2002). In this experiment, both spots of 4 and 9 in 'Maghan3' showed increase expression under stress while these protein spots showed reduced expression in 'Pishtaz' (Table 3). Wan and Liu (2008), Naghavi (2010) and Naghavi (2014), found similar results in leaves of rice, canola and wheat under hydrogen peroxide, osmotic and drought stresses, respectively. Also, Ye et al. (2013) reported that 72 hours after stress imposed by PEG, the increased expression of RuBisCO took place in wheat leaves. This increase helped plants during drought stress with the increase of assimilation and better efficiency of photosynthesis in using of carbon dioxide and enables plants to overcome the stress. On the other hands, Calvin cycle consists of three phases. The third phase of the cycle is regeneration of RuBP molecules and Calvin cycle starts from the beginning. This phase is known by a series of enzymatic reactions in which triosephosphate is converted to RuBP. Enzymes intermediary or mediatory in this phase include sedoheptulose-1,7biphosphate and fructose 1,6-biphosphate aldolase (spot No. 12). Together these two enzymes catalyze a reaction that eventually results in the formation of ribulose-5phosphate. Then ribulose-5-phosphate is phosphorylated and forms RuBP (Tamoi et al., 2005). Thereby reducing the mediator enzyme in this process (spots 12) in susceptible cultivar ('Pishtaz') causes reduction of efficiency of Calvin cycle and reduces sugar production. On the other hand, it is reported that photosynthesisrelated proteins such as RuBisCO activaze (spot no. 5) (Table 3) showed decreased expression in susceptible cultivar of barley under stress condition (Kausar et al., 2013).

\section{Other protein groups}

A total two common spots such as 1 and 2 (with upregulated in 'Moghan3' and down-regulated in 'Pishtaz') and one spots in the 'Pishtaz' (spot code J with absent expression under stress condition) were detected as different subunits of ATP synthase complex (Tables 3, 4). In previous experiments different subunit components of this complex in canola (Albertin et al., 2009) and leaves of corn (Porubleva et al., 2001) have been identified. Structurally, ATP synthase in chloroplast has two main components which include extrinsic CF1 and CF0.With their help protons are transmitted over the thylakoid membrane. CF1 has five subunits, alpha, beta (common spots No. 1 and 2), gamma, delta (spot code $\mathrm{J}$ in the 'Pishtaz') and epsilon while CF0 has three subunits a, b and c (von Ballmoos and Dimroth, 2007). One of these subunits is the $\beta$ subunit, which is a catalytic and ADP-binding unit.It plays an important role in energy conversion by converting ADP to ATP when there is a proton-slope between the membranes (Ye et al., 2013). Increased expression of ATP synthesis-associated proteins under abiotic stress conditions, including drought and salinity, have been reported in previous studies (Guo et al., 2012).

Heat shock proteins (spot No. 3 and spot code A) (Tables 3 and 4) are molecular chaperones. These proteins help to stabilize and regenerate the proteins that have been opened and decomposed during various stresses. These proteins play a decisive role in plant 
protection against stress to restore proteins to their original natural form and are involved in the establishment of cell homeostasis (Wang et al., 2004). Toorchi et al. (2009) reported on reduced expression of these proteins in soybean under osmotic stress. While, Naghavi (2010) working on canola tolerant cultivar under drought stress noticed increased expression of these proteins. In other study Naghavi (2014) reported that these proteins showed decreased expression in wheat under the drought stress, in susceptible cultivar a decreased expression was bigger than in tolerant one.

\section{CONCLUSIONS}

According to the results, 198 and 203 protein spots in tolerant and susceptible cultivars were identified, among them 21 and 22 protein spots with significantly different IF were identified, respectively. A total of 16 protein spots were identified common for both, tolerant and susceptible cultivars under salinity stress. The majority of these proteins were involved in removal of oxidants where the highest activity had 2-cys peroxiredoxin BAS1, chloroplast protein and the Calvin cycle proteins (among them were the most common subunits of Rubisco). In addition, five protein spots were present only in the tolerant cultivar. Majority of them were involved in the removal of oxidants. Due to increased expression of these proteins in tolerant cultivar it had better performance of cellular detoxification. Six protein spots were found uniquely in the sensitive cultivar. Majority of these proteins were related to light reactions of photosynthesis. According to the decreased expression of these proteins a reduction of photosynthesis performance under salinity stress appeared in susceptible cultivar.

\section{ACKNOWLEDGMENTS}

The financial support of this experiment was performed by the research grant of Payame Noor University under support of Ministry of Science, Research and
Technology's information of Iran. The authors also thank to all of unknown reviewers for their most useful comments on the manuscript.

\section{REFERENCES}

Abdul Kader, M. D. and Lindberg, S. (2010). Cytosolic calcium and $\mathrm{pH}$ signaling in plants under salinity stress. Plant Signaling and Behavior, 5, 233-238. doi:10.4161/psb.5.3.10740

Albertin, W., Langella, O. Joets, J. Negroni, L. Zivy, M. Damerval C. and Thiellement, H. (2009). Comparative proteomics of leaf, stem, and root tissues of synthetic Brassica napus. Proteomics, 9, 793-799. doi:10.1002/pmic.200800479

Athar, H. U. R. Khan, A. and Ashraf, M. (2008). Exogenously applied ascorbic acid alleviates Saltinduced oxidative stress in wheat. Environmental and Experimental Botany, 63, 224-231. doi:10.1016/j.envexpbot.2007.10.018

Bradford, M. M. (1976). A rapid and sensitive method for the quantitation of microgram quantities of protein utilizing the principle of protein-dye binding. Analytical biochemistry, 72, 248-254. doi:10.1016/0003-2697(76)90527-3

Cakmak, I. (2005). The role of potassium in alleviating detrimental effects of abiotic stresses in plants.
Journal of Plant Nutrition and Soil Science, 168, 521-530. doi:10.1002/jpln.200420485

Eberhard, S., Finazzi, G. and Wollman, F. A. (2008). The dynamics of photosynthesis. Annual Review of Genetics, 42, 463-515. doi:10.1146/annurev.genet.42.110807.091452

Fatehi, F., Hosseinzadeh, A. Alizadeh, H. Brimavandi T. and Struik, P. C. (2012). The proteome response of salt-resistant and salt-sensitive barley genotypes to long-term salinity stress. Molecular Biology Reports, 39, 6387-6397. doi:10.1007/s11033-012$1460-\mathrm{z}$

Ford, K. L., A. Cassin, and Bacic, A. (2011). Quantitative proteomic analysis of wheat cultivars with differing drought stress tolerance. Plant Science, 2(44), 1-11.

Gao, L., Yan, X. Li, X. Guo, G. Hu, Y. Ma W. and Yan, Y. (2011). Proteome analysis of wheat leaf under salt stress by two-dimensional difference gel electrophoresis (2D-DIGE). Photochemistry, 72(10), 1180-1191. 
Granlund, I., Storm, P. Schubert, M. Garcia-Cerdi, J. G. Funk C. and Wolfgang, P. S. (2009). The TL29 Protein is Lumen Located, Associated with PSII and Not an Ascorbate Peroxidase. Plant and Cell Physiology, 50(11), 1898-1910. doi:10.1093/pcp/pcp134

Guo, G., Ge, P. Ma, C. Li, X. Lv, D. Wang, S. Ma W. and Yan, Y. (2012). Comparative proteomic analysis of salt response proteins in seedling roots of two wheat varieties. Journal of Proteomics, 75(6), 1867-1885. doi:10.1016/j.jprot.2011.12.032

Hashimoto, M., Toorchi, M. Matsushita, K. Iwasaki Y. and Komatsu, S. (2009). Proteome analysis of rice root plasma membrane and detection of cold stress responsive proteins. Protein \& Peptide Letters, 16, 685-697. doi:10.2174/092986609788490140

Heide, H., Kalisz H. M. and Follmann, H. (2004). The oxygen evolving enhancer protein 1 (OEE) of photosystem II in green algae exhibits thioredoxin activity. Journal of Plant Physiology, 161, 139-149. doi:10.1078/0176-1617-01033

Herbert, B. (1999). Advances in protein solubilisation for two-dimensional electrophoresis. Electrophoresis, 20(4-5), 660-663. doi:10.1002/(SICI)15222683(19990101)20:4/5<660::AIDELPS660>3.0.CO;2-Q

Hosseini Salekdeh, Gh., Siopongco, J. Wade, L. J. Ghareyazie B. and Bennett, J. (2002). Proteomics analysis of rice leaves during drought stress and recovery. Proteomics, 2, 1131-1145. doi:10.1002/1615-9861(200209)2:9<1131::AIDPROT1131>3.0.CO;2-1

Ifuku, K., Ishihara, S. Shimamoto, S. Ido K. and Sato, F. (2008). Structure, function, and evolution of the PsbP protein family in higher plants. Photosynthesis Research, 98, 427-437. doi:10.1007/s11120-008-9359-1

Joseph, B. and Jini, D. (2010). Proteomic analysis of salinity stress-responsive proteins in plants. Asian Journal of Plant Sciences, 9, 307-313. doi:10.3923/ajps.2010.307.313

Kausar, R., Arshad. M. Shahzad A. and Komatsu, S. (2013). Proteomics analysis of sensitive and tolerant barley genotypes under drought stress. Amino Acids, 44, 345-359. doi:10.1007/s00726012-1338-3

Kieselbach, T. Bystedt M. and Zentgraf, U. (2000). A peroxidase homologue and novel plastocyanin located by proteomics to the Arabidopsis chloroplast thylakoid lumen. Febs Letters, 480(23), 271-276. doi:10.1016/S0014-5793(00)01890-1
Komatsu, S. and Tanaka, N. (2004). Rice proteome analysis: A step toward functional analysis of the rice genome. Proteomics, 4, 938-949.

Liu, S., Liu, S. Wang, M. Wei, T. Meng, C. Wang, M. and Xia, G. (2014). A wheat SIMILAR TO RCDONE gene enhances seedling growth and abiotic stress resistance by modulating redox homeostasis and maintaining genomic integrity. The Plant Cell, 26, 164-180. doi:10.1105/tpc.113.118687

Mittler, R. (2002). Oxidative stress, antioxidants and stress tolerance. Trends in Plant Science, 7, 405410. doi:10.1016/S1360-1385(02)02312-9

Morant-Manceau, A., Pradier E. and Tremblin, G. (2004). Osmotic adjustment, gas exchanges and chlorophyll fluorescence of a hexaploid triticale and its parental species salt stress. Journal of Plant Physiology, 169, 25-33. doi:10.1078/0176-161700963

Naghavi, M. R. (2014). Evaluation of spring wheat cultivars under drought stress and proteome analysis for the most tolerant and sensitive ones. $\mathrm{PhD}$ Thesis in Plant Breeding (Biometrical Genetics). Department of Plant Breeding and Biotechnology. Faculty of Agriculture. University of Tabriz, Iran. (In Persian).

Naghavi, M. R. (2010). Response and 2-Dimensional electrophoresis pattern of spring rapeseed genotypes under osmotic stress. Master Science Dissertation in Plant Breeding. Department of Agronomy and Plant Breeding. Faculty of Agriculture, University of Tabriz, Iran. (In Persian).

Noreen, S. and Ashraf, M. (2008). Alleviation of adverse effects of salt stress on sunflower (Helianthus annus L.) by exogenous application of salicylic acid: Growth and photosynthesis. Pakistan Journal of Botany, 40, 1657-1663.

Panchuk, I. I., Zentgraf U. and Volkov, R. A. (2005). Expression of the Apx gene family during leaf senescence of Arabidopsis thaliana. Planta, 222(5), 926-932. doi:10.1007/s00425-005-0028-8

Plucken, H., Muller, B. Grohmann, D. Westhoff P. and Eichacker, L. A. (2002). The HCF136 proteinis essential for assembly of the photosystem II reaction center in Arabidopsis thaliana. FEBS Letters, 532, 85-90. doi:10.1016/S00145793(02)03634-7

Porubleva, L., Vander Velden, K. Kothari, S. Oliver D. J. and Chitnis, P. R. (2001). The proteome of maize leaves: use of gene sequences and expressed sequence tag data for identification of proteins with peptide mass fingerprints. Electrophoresis, 22, 1724-1738. doi:10.1002/1522- 
2683(200105)22:9<1724::AID-

ELPS1724>3.0.CO;2-2

Saqib, M., Zorb C. and Schubert, S. (2006). Saltresistant and salt-sensitive wheat genotypes show similar biochemical reaction at protein level in the first phase of salt stress. Journal of Plant Nutrition and Soil Science, 169, 542-548. doi:10.1002/jpln.200520557

Song, X. Ni, Z. Yao, Y. Xie, C. Li, Z. Wu, H. Zhang, Y. and Sun, Q. (2007). Wheat (Triticum aestivum L.) root proteome and differentially expressed root proteins between hybrid and parents. Proteomics, 7(19), 3538-3557. doi:10.1002/pmic.200700147

Spreitzer, R. J. and Salvucci, M. E. (2002). Rubisco: structure, regulatory interactions, and possibilities for a better enzyme. Annual Review of Plant Biology, 53, 449-475. doi:10.1146/annurev.arplant.53.100301.135233

Sun, Y., Ahokas, R. A. Bhattacharya, S. K. Gerling, I. C. Carbone L. D. and Weber, K. T. (2006). Oxidative stress in aldosteronism. Cardiovascular Research, 71, 300-309. doi:10.1016/j.cardiores.2006.03.007

Takahashi, S. and Murata, N. (2008). How do environmental stresses accelerate photo inhibition? Trends in Plant Science, 13, 178-182. doi:10.1016/j.tplants.2008.01.005

Tamoi, M., Nagaoka, M. Yabuta Y. and Shigeoka, S. (2005). Carbon metabolism in the Calvin cycle. Plant Biotechnology, 22, 355-360. doi:10.5511/plantbiotechnology.22.355

Thiellement, H., Zivy M. and Plomion, C. (2002). Combining proteomic and genetic studies in plants. Chromatography $\quad B, \quad 782, \quad 137-149$. doi:10.1016/S1570-0232(02)00553-6

Toorchi, M., Yukawa, K. Nouri M. Z. and Komatsu, S. (2009). Proteomics approach for identifying osmotic-stress-related proteins in soybeans roots. Peptides, 30, 2108-2117. doi:10.1016/j.peptides.2009.09.006
Tuteja, N. (2007). Mechanisms of high salinity tolerance in plants. Methods in Enzymology, 428, 419-438. doi:10.1016/S0076-6879(07)28024-3

Twyman, R. M. (2004). Principles of proteomics. BIOS Scientific Publishers. doi:10.4324/9780203507391

von Ballmoos, C. and Dimroth, P. (2007). Two distinct proton binding sites in the ATP synthase family. Biochemistry, 46, 11800-11809. doi:10.1021/bi701083v

Wan, X. Y. and Liu, J. Y. (2008). Comparative proteomics analysis reveals an intimate protein network provoked by hydrogen peroxide stress in rice seedling leaves. Molecular \& Cellular Proteomics, $7, \quad 1469-1488$. doi:10.1074/mcp.M700488-MCP200

Wang, W., Vinocur, B. Soseyov O. and Altman, A. (2004). Role of plant heat-shock proteins and molecular chaperones in the abiotic stress response. Trends in Plant Science, 9, 244-52. doi:10.1016/j.tplants.2004.03.006

Xue, G. P., Mcintyre, C. L. Glassop D. and Shorter, R. (2008). Use of expression analysis to dissect alterations in carbohydrate metabolism in wheat leaves during drought stress. Plant Molecular Biology, 67, 197-214. doi:10.1007/s11103-0089311-y

Ye, J., Wang, S. Zhang, F. Xie D. and Yao, Y. (2013). Proteomic analysis of leaves of different wheat genotypes subjected to $\mathrm{PEG}_{6000}$ stress and rewatering. Plant Omics Journal, 6(4), 286-294.

Zadraznik, T. Hollung, K. Egge-Jacobsen, W. Meglic, V. and Sustar-Vozlic, J. (2013). Differential proteomic analysis of drought stress response in leaves of common bean (Phaseolus vulgaris L.). Journal of Proteome, 78, 254-272. doi:10.1016/j.jprot.2012.09.021

Zhu, M., Simons, B. Zhu, N. David, G. Oppenheimer M. and Chen, S. (2010). Analysis of abscisic acid responsive proteins in Brassica napus guard cells by multiplexed isobaric tagging. Journal of Proteomics, 73, 790-805. doi:10.1016/j.jprot.2009.11.002 